分解し， ADCT となる7)ことが知られている)。

よって，(i)，(ii）のいずれであるかを明らかにするため CC とシアン酸カリウムとの反㐫液にエチルアルコールを加えたとこ ろ、エチルアルコール添加の洔期などによって生成物が異なり, エチルアルコールの添加までの加熱時間が長いと ADCT を生成 するが，加熱開始後エチルアルコールを加えるまでの時間が適当 （ほぼ5 分）だと最高 60\% 程度の収率で 2, 4-ジクロルー6-エト キシカルボニルアミノーงートリアジンを得た。この場合, 反応の条 件からみてまずウレタンが生成し，これが CC と縮合して 2,4ジクロル-6-エトキシカルボニルアミノーงートリアジンを生成する という経路も考えられるが，CC とウレタンをアセトン中で加熱 してもほぼ定量的に CC を回収するにすぎず，上記反応がこのよ うな経路で進んでいるとは認め難い。以上，ADCT の生成は，

7）児玉，関場，有機合成化学，21，888（1963）. (ii）の経路によるとみられ，結果を表 2 に示した。なお，CC と シアン酸カリウムの反応で大過剩のシアン酸カリウムを用いても 2 個の活珄塩素の置換生成物は得られなかった。<smiles>[X]C(=O)OC</smiles>

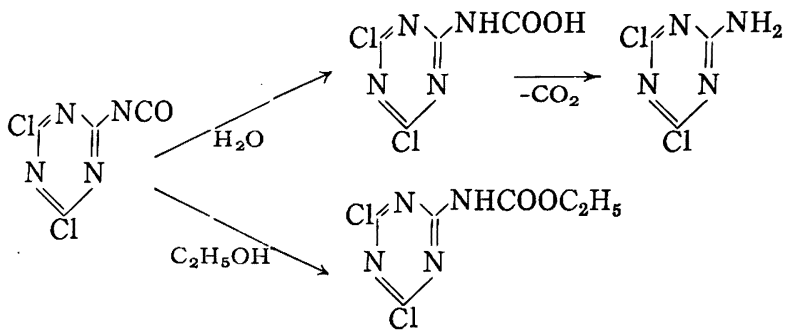

\title{
ポリ $\boldsymbol{p}$-メトキシスチリルラジカルの置換クメン誘導体への連鎖移動反応の置換基効果*1
}

(昭 和 42 年 5 月 22 日受理)

\author{
山本 忠弘 ${ }^{* 2} \cdot$ 大津 隆 行 ${ }^{* 3}$
}

\section{1 緒言}

藷者らは前報1)で, 種々のポリマーラジカルによる置換クメン への連鎖移動反応性がハメット式に従わず，むしろ共鳴項 $\left(\gamma E_{\mathrm{R}}\right)$ を含むハメット拡張式致によって良好に関係づけられることを述 ベた。

$$
\log \left(k / k_{0}\right)=\rho \sigma+\gamma E_{\mathrm{R}}
$$

ここで $\sigma$ と $E_{\mathrm{R}}$ は極性および共鳴置換基定数， $\rho$ と $\gamma$ は極性 および共鳴の程度を示す反応定数である。

本報では，連鎖移動反応の攻撃ラジカル側の置換基効果につい ても詳細に検討する目的で， $p$-メトキシスチレンの重合に拈ける 置換クメンの連鎖移動定数を測定した。

\section{2 実験}

6 種の置換クメン（表 1 参照）を用い，クメンを除いて他は合

*1 本報文を「ビニル重合（第182 報)」とする.

*2 Tadahiro YAMAMOTO 姫路工業大学：姫路市伊伝居.

*3 Takayuki OTSU 大阪市立大学工学部：大阪市住吉区杉 本町.

1) T. Yamamoto, T. Otsu, J. Polymer Sci., B, 4, 1039 (1966).

2）大津, 山本, 有機合成化学, 23，643 (1965)；Chemistry and Industry, 1967, 787.

3) T. Yamamoto, Bull. Chem. Soc. Japan, 40, 642(1967).

4）木下, 井本, 高分子化学, 20，231（1963）.

5) T. Alfrey, A.Bartovics, H. Mark, J. Am. Chem. Soc., 65, 2319 (1943).

6) F. R. Mayo, R. A. Gregg, M.S. Matheson, ibid., 73, 1691 (1951).

7) McDaniel, H.C.Brown, J. Org.Chem., 23, 425 (1958). 成した3)。p-メトキシスチレンは木下らの方法4)で合成した。す べての化合物は使用前に再び蒸留して用いた。重合は前報3) と同 様にして，一定量のモノマー，クメン誘導体和よび開始剂として アゾビスイソブチロニトリル $\left(3.62 \times 10^{-3} \mathrm{~mol} / l\right)$ を加えた封管中 $60^{\circ} \mathrm{C}$ の恒温槽中で行なった。重合体の数平均重合度 $\left(\bar{P}_{n}\right)$ はへ ンゼン中, $30^{\circ} \mathrm{C}$ の粘度を測定し, 極限粘度 $([\eta])-\bar{P}_{n}$ 関係式 から求めた。

$$
\log \bar{P}_{n}=3.472+1.43 \log [\eta]
$$

連鎖移動定数 (C) は Mayo 式6) から求めた。

\section{3 結果および考察}

これらクメン誘導体中に打ける $p$ ーメトキシスチレンの重合速 度は, 制作用も認められない。表 1 に得られた $C$ 値を示す。

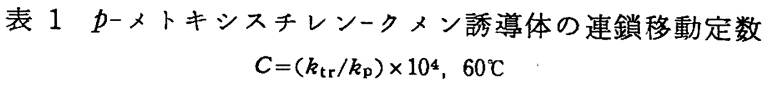

\begin{tabular}{cccc}
\hline $\mathrm{X}$ & $\sigma^{7)}$ & $E_{\mathrm{R}}$ & \multicolumn{1}{c}{$C$} \\
\hline$p-\mathrm{CH}_{3} \mathrm{O}$ & -0.268 & 0.11 & 3.40 \\
$p-$ tert- & -0.197 & 0.03 & 3.64 \\
$\mathrm{C}_{4} \mathrm{H}_{9}$ & 0.00 & 0.00 & 4.28 \\
$\mathrm{H}$ & 0.227 & 0.10 & 8.52 \\
$p-\mathrm{Cl}$ & 0.232 & 0.12 & 11.8 \\
$p-\mathrm{Br}$ & 0.660 & 0.24 & 40.9 \\
$p-\mathrm{CN}$ & & &
\end{tabular}

表から電子吸引基をもつ誘導体の $C$ 値は, 無置換クメンの $C$ 值 (三 $\left.C_{0}\right)$ 上り 大きく，一方電子供給基をもつ誘導体は幾分小さく なった。表 1 の值を用い, 次式で示すハメットプロットを図示す ると図 1 のようになる。

$$
\log \left(C / C_{0}\right)=\rho_{O}
$$




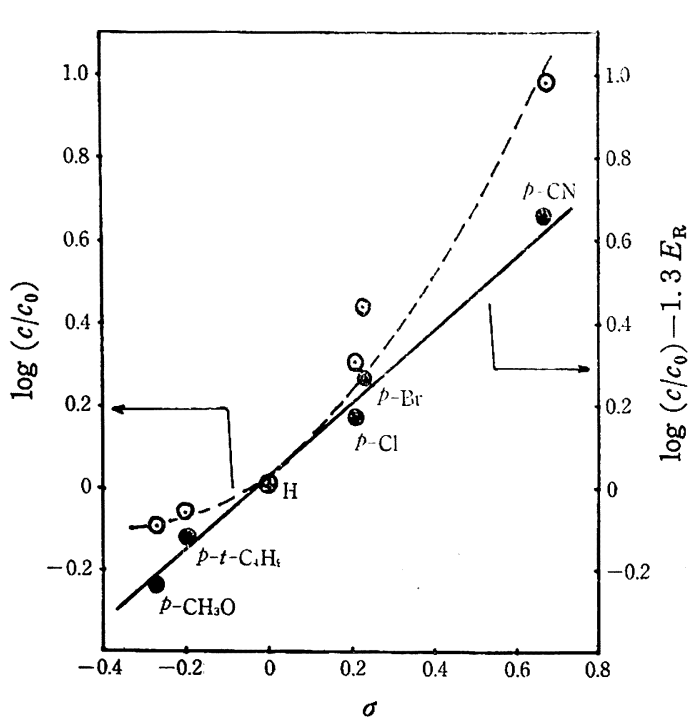

図1ハメット式と（1）式の適用

図から明らかなよらに直線関係は得られなかっだ4。特に電子 供給性の置換基の反応性はそのハメットプロットから予想される よりも大きかった。つぎに（1）式の適用を試みた所， $r=1.3$ と おいて, $\log \left(C / C_{0}\right)-1.3 E_{\mathrm{R}}$ と $\sigma$ 定数との間に直線関係が成立

*4 図 1 の傾きから本反応は求核的反応であると考えられるの で, $\sigma$ 定数の代りに $\sigma^{-}$值を用いたが，直線性はよくはな らない。

した（図1の実線）。したがってこの結果，本反応の置換基效果 は明らかに共鳴効果もまた無視できないことが前報1)と同様に認 められた。

表 2 に数種の $p$-置換スチリルラジカルと置换クメンとの反応 で（1）式の適用から得られた反応定数の值を示す。

表 2 えられた $\rho$ と值

\begin{tabular}{|c|c|c|c|}
\hline 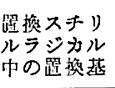 & $\rho$ & $\gamma$ & 文 献 \\
\hline$p-\mathrm{Cl}$ & +0.2 & 1.0 & 1) \\
\hline $\mathrm{H}$ & +0.7 & 1.0 & 3) \\
\hline$p-\mathrm{CH}_{3}$ & +0.8 & 1.1 & 8) \\
\hline$p-\mathrm{CH}_{3} \mathrm{O}$ & +1.0 & 1.3 & 本反応 \\
\hline
\end{tabular}

本反応で得られた $\rho$ 值は， $p$-メチルスチリルラジカルの攻㧘の 場合のそれよりも正に大きい值であった。そして。值の大きさは 攻撃ラジカル側の置換基の極性の順に従らことが明らかに示され た。一方の值は，本反応に拈いては多少大きい值を示したが， 表 2 に示した 4 種の $p$-置換ポリスチリルラジカルの場合を比べ ると著しい差異は認められなかった。

したがって，p-置換ポリスチリルラジカルによる $p$-置換クメ ンへの連鎖移動反応性に特よぼすクメン側の置換基の極性効果 （ $\rho ）$ は, 攻撃ラジカル側の置換基の極性效果によって変化する が, 共鳴効果 $(r)$ はほとんど変化しないことが認められた。

8）山本, 大津, 井本, 工化, 69, 990 (1966).

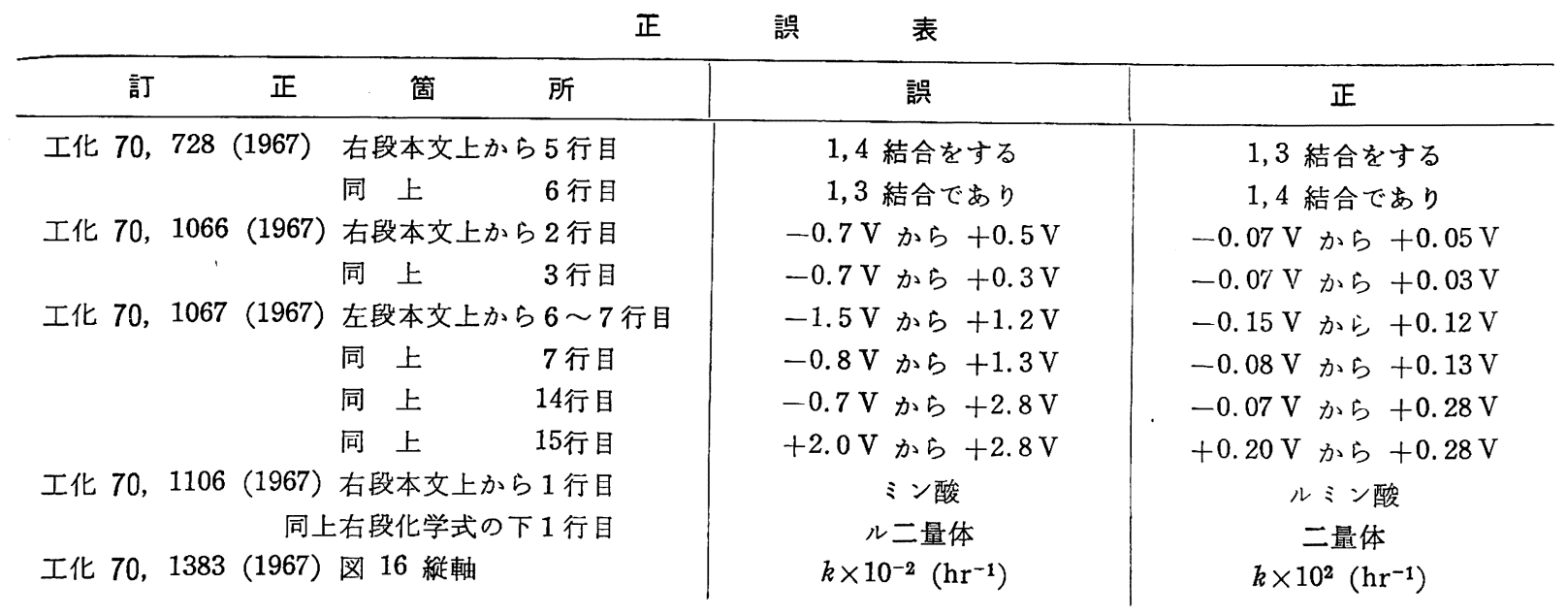

昭和 42 年 12 月 5 日発行 (定仰 400 月(送料 30 円) ) 登行萧 東京都千代田区神㽤駇河台 1 の 5

印刷人東京都新宿区市々谷本村町 27 印刷所東京都新宿区市分谷本村町 27
岩城広吉

岩永吉光

新日本印别株式会社

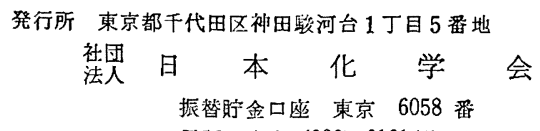

発行所 東京都干代田区被田駿河台 1 丁目 5 番地 袪団日本化学会 振替眝金口座 東京 6058 番 電話 東京 (292) 6161(代裴)

(C) 1967 The Chemical Society of Japan 